\title{
TRACE METALS CONTAMINATION OF GROUNDWATER IN AND AROUND TANNERY INDUSTRIAL AREA OF PALLAVARAM, CHENNAI CITY, INDIA
}

\author{
K.Ramesh $^{1}$, V.Thirumangai ${ }^{2}$ \\ ${ }^{I}$ Assistant Professor, Centre for Water Resources, Anna University, Chennai, Tamil Nadu, India \\ ${ }^{2}$ Teaching Fellow, Centre for Water Resources, Anna University, Chennai, Tamil Nadu, India
}

\begin{abstract}
Water is very essential part of all living organisms. Due to urbanization and industrialization, various contaminants are added to water sources through waste discharge resulting in the gradual degradation of water quality. The heavy metals are one type of toxic elements and are mostly released from industrial effluents. Due to various reasons water become polluted with toxic metals. A study was conducted on Tannery industrial area of Pallavaram in January 2014 and the groundwater samples were collected and were analyzed for heavy metal contamination. The heavy metals like $\mathrm{Cr}, \mathrm{Cu}, \mathrm{Pb}, \mathrm{F}$ and $\mathrm{Zn}$ were analyzed in groundwater samples. The results were compared with standards prescribed by BIS. The result indicated the higher concentration of $\mathrm{Cr}$ and $\mathrm{Pb}$ metals found in the groundwater samples. From the results it is clearly evident that the groundwater of the study area is contaminated due to the industrial effluents and solid waste dumpsite and overall water quality was found unsatisfactory for drinking purposes. Thus water quality indicates that pollution of the water is increasing alarmingly and that it has created serious threat to human health.
\end{abstract}

Keywords: Groundwater Quality, Heavy metals, Tanneries, impact.

\section{INTRODUCTION}

Groundwater forms a major source of drinking water. The environmental impact of human activity on the groundwater is considered as one of the major hazard in the modern days. In the last few decades, there has been a tremendous increase in the demand for fresh water due to rapid growth of population and the industrialization has affected the availability and quality of groundwater due to its over exploitation and improper waste disposal especially in urban areas [1]. Water pollution is a major problem globally and it has been found that it is leading to worldwide cause of death and disease.

Heavy metal in water is a major problem in India. Some heavy metals are very essential in human health, but they may cause various health problems, if present in higher concentration. Therefore the heavy metal concentration in drinking water should be kept in low ppb range. It threatens the life of human and animals as well as effects on environment. Environmental pollution is a major problem in developing countries due to rapid urbanization industrialization. Heavy metals can accumulate in living organisms in living organisms and cause various diseases [2]. About 5 million people died due to diseases caused from impure water and toxic metals present in water [3]. Heavy metal toxicity is potentially dangerous because of bioaccumulation though the food chain and this can cause hazards effects on livestock and human health [4-5]. The consequence of urbanization and industrialization lead to spoilage the groundwater. During last decades this is observed that the groundwater get polluted drastically because of increased human activities [6]. In many parts of the country available water is rendered non-potable because of the presence of heavy metals in excess. The objective of this study therefore is to determine the levels of some heavy metals in groundwater sources in Pallavaram municipality town, Chennai. The analyzed data were compared with standard values recommended by BIS.

\section{MATERIALS AND METHODS}

In order to assess groundwater 18 samples were collected from the tannery accumulated site Pallavaram, Tamil Nadu, India (Table-1) during January 2014. The $\mathrm{pH}$ and electrical conductivity (EC) were measured at the sample site using handheld analyzing kits. Groundwater samples were collected and the samples were kept in a polythene bottle for further laboratory analysis of major ions. The extra pure analytical reagents and chemical standards were used for the groundwater quality assessment. The analytical procedures are suggested by the American Public Health Association [7]. Chromium $(\mathrm{Cr})$, Copper $(\mathrm{Cu})$, Lead $(\mathrm{Pb})$, Fluoride $(\mathrm{F})$ and Zinc $(\mathrm{Zn})$ are determined using the Atomic Absorption Spectrophotometer. The location of the wells where the groundwater has been collected is represented in the following map processed by Field-Pro. 
Table-1: Table with Sample Details of Study Area

\begin{tabular}{|c|l|l|}
\hline $\begin{array}{l}\text { Sampling } \\
\text { Wells No }\end{array}$ & Sampling Locations & $\begin{array}{l}\text { Source/ } \\
\text { Type of Well }\end{array}$ \\
\hline 1 & $\begin{array}{l}\text { Darga Road ,Zamin } \\
\text { Pallavaram }\end{array}$ & Bore well \\
\hline 2 & Murugavel Nagar & Bore well \\
\hline 3 & Periyar Nagar & Open well \\
\hline 4 & $\begin{array}{l}\text { Thuraipakkam-Pallavaram } \\
\text { Link Road }\end{array}$ & Open well \\
\hline 5 & Arundahipuram & Open well \\
\hline 6 & Sawadi St & Bore well \\
\hline 7 & Narayanasamy St & Bore well \\
\hline 8 & Cantonment & Bore well \\
\hline 9 & Muthamigh Road & Bore well \\
\hline 10 & Abdul Farqe Sahib St & Bore well \\
\hline 11 & Near Police Station & Bore well \\
\hline 12 & Sandy Road & Bore well \\
\hline 13 & Iswarya Nagar & Bore well \\
\hline 14 & Radhanagar & Open well \\
\hline 15 & CLS Work Road & Bore well \\
\hline 16 & GST Road & Open well \\
\hline 17 & Kodandan Nagar & Bore well \\
\hline 18 & Bore well \\
\hline
\end{tabular}

\subsection{Study Area}

The study area Pallavaram Township is an industrial area located in Chennai Metropolitan city, Tamil Nadu (Fig-1). The study area is $13 \mathrm{~km}$ away from the Bay of Bengal. A large number of tannery industries are located for about two kilometers length on both sides of the road. The area has lots of large scale and small scale tanning industries. Chrome tanning is the popular method practiced in this area. The area has Periya eri (big tank), once a sprawling water body covering about 189 acres, now shrunken into to small patch and used as storage for effluents from leather industry, sewage and dumping of garbage which has adversely affected the quality of the groundwater. Unpleasant smell prevails in the locality surrounding this area due to the heavy loads of industrial effluents. The climatic condition is hot during summer (March to June) and cold during winter season (November to January). The area receives rainfall from both south-west (June to September) and northeast monsoon
(October to December) and the area enjoys a tropical climate. The climate of the area is with low humidity and high temperature, and the temperature is around $18^{\circ} \mathrm{C}-25^{\circ} \mathrm{C}$ during winter and during summer has a maximum of $35^{\circ} \mathrm{C}-42^{\circ} \mathrm{C}$ and is generally hot. Temperature starts rising towards the end of February. Geologically the study area is covered by crystalline rocks of Archaean age consisting of Charnockite formation. Pallavaram is a satellite town for Chennai city, is well connected network of road and railway line, located on south Chennai Grand Southern Trunk Road (National Highways 45) and along the Chennai-Tambaram railway line.

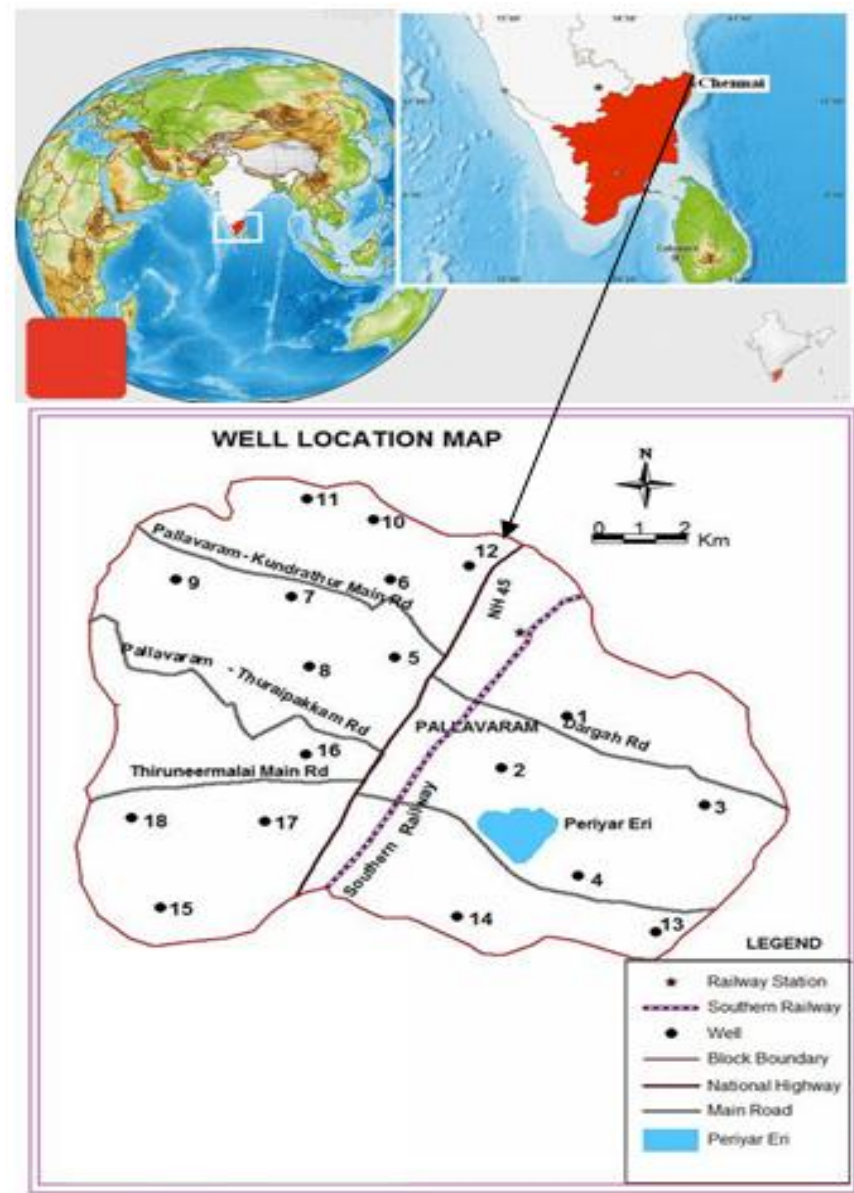

Fig-1: Location map of study area

\section{RESULTS AND DISCUSSION}

\subsection{Heavy Metals (Trace Element)}

Heavy metals are natural components of the earth's crust and it refers to any metallic chemical element that has a relatively high density (more than $5 \mathrm{mg} / \mathrm{l}$ ) and is toxic at low concentrations [8]. Study of heavy metal concentrations in the water is the great importance due to their direct influences on human health, animals and plant livings. The inorganic industrial materials, rock weathering and human activities is considered essential source for water contaminate by heavy 
element. The elements are usually found as natural components of Earth. Drinking water containing high levels of these essential metals such as $\mathrm{Cu}, \mathrm{Cr}, \mathrm{Zn}$ and $\mathrm{Pb}$ may be hazardous to our health. The concentration of these metals in water varies from place to place. A total of 18 groundwater samples were collected in and around Pallavaram town during the month of January 2014 and test results are described below.

\subsection{Electrical Conductivity (EC)}

Electrical Conductivity (EC) is the ability of $1 \mathrm{~cm}^{3}$ of water to conduct electric current at temperature of $25^{\circ} \mathrm{C}$, when measured by micro Siemens per centimeter $(\mu \mathrm{S} / \mathrm{cm})$. It depends on the concentration of soluble salts and the temperature of the water [9]. The EC depends on water temperature, where an increase of one degree Celsius causes an increase in electrical conductivity by (2\%) [10]. Also the EC increases with the increase of the total dissolved salts. The electrical conductivity values ranges from $983 \mu \mathrm{Scm}^{-1}$ to $14725 \mu \mathrm{Scm}^{-1}$ with an average of $3157 \mu \mathrm{Scm}^{-1}$ (Fig-2). The electrical conductivity value in the study was very high which may be due to quantity of skins and hides processed and the amounts of salts used and also from solid waste dumping site. The most of the samples exceed the permissible limit of EC in drinking water is prescribed as $1500 \mu \mathrm{Scm}^{-1}$ [21]. Higher EC in the study area indicates the acid-base and the enrichment of salts in the groundwater.

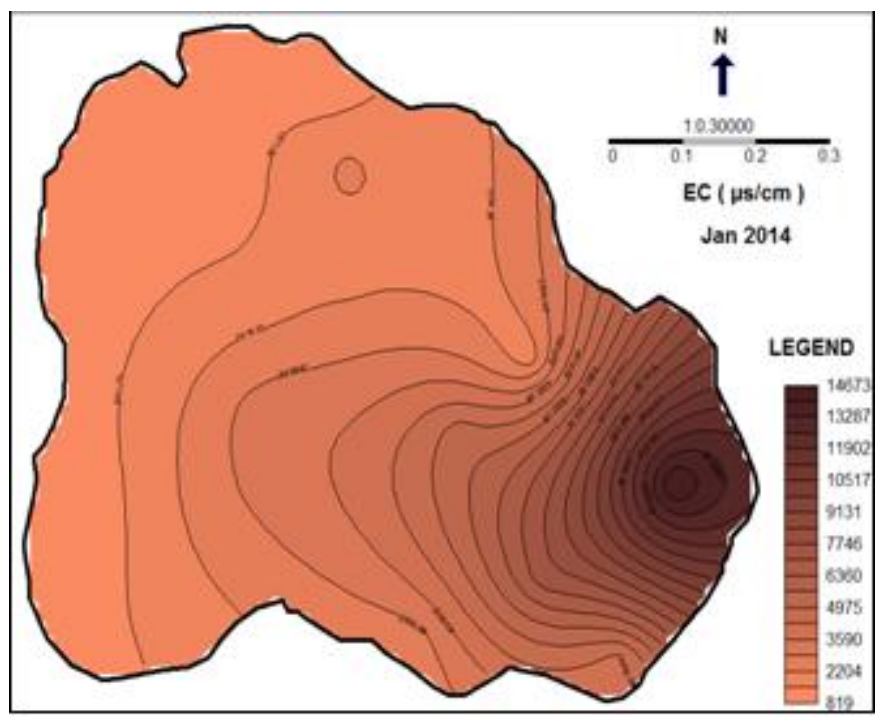

Fig-2: Spatial Variation of EC

\subsection{Total Hardness (TH)}

The hardness of groundwater predominantly results from the presence of dissolved calcium and magnesium salts usually carbonates. The term hard and soft as applied to water date from Hippocrates (460-354 B.C) the father of medicine in his treatise on public hygiene. Hardness is a measure of the effect of water on the ability of soap to form suds, to cause scaling problems in pipe work and heating systems due to the nature of the dissolved salts. Hardness is an important criterion in determining the suitability of water samples for domestic and industrial purposes. Total hardness found in the sample ranges from $77 \mathrm{mg} / \mathrm{l}$ to $1831 \mathrm{mg} / \mathrm{l}$ in groundwater with an average of $682 \mathrm{mg} / \mathrm{l}$ which shows (Fig-3) that almost majority of water samples is not safe for drinking purpose. The hardness of the water is due to the presence of alkaline earths such as calcium and magnesium. The TH (in $\mathrm{mg} / \mathrm{l}$ ) was determined as: $\mathrm{TH}=2.497 \mathrm{Ca}^{2+}+4.115 \mathrm{Mg}^{2+}$

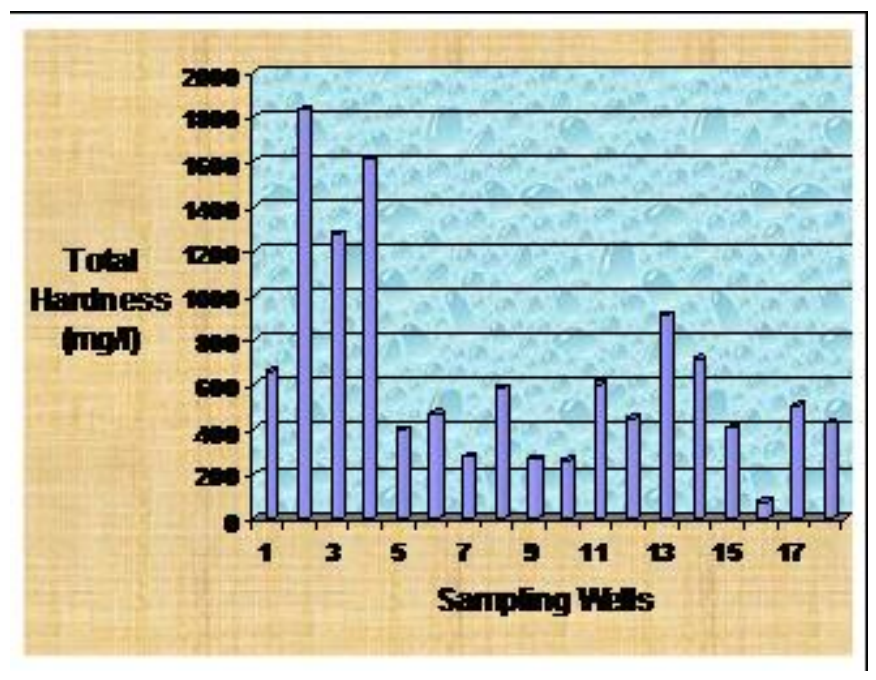

Fig-3: Variation of Total Hardne

The classification of groundwater samples based on hardness [13] revealed that most of the samples belong to hard to very hard category. High levels $(>300 \mathrm{mg} / \mathrm{l})$ of hardness may affect water supply system, excessive soap consumption, calcification of arteries and cause urinary concentrations, diseases of kidney of bladder and stomach disorders [14].

\subsection{Fluoride ( $\left.\mathbf{F}^{-}\right)$}

One of the main trace elements in groundwater is fluoride which generally occurs as natural constituent. Bedrock containing fluoride minerals is generally responsible for higher concentration of this ion in groundwater. Fluoride is added to some consumer products such as toothpaste, toothpowder, mouth wash, etc., Fluoride increases the resistivity of tooth enamel against acids which causes the initiation of tooth decay. It reduces tooth decay about 40-50\%. Fluoride normally accumulates in the bones, teeth and calcified tissues of the human body. Excess of fluoride in water causes serious damage to the teeth and bones of the human body, which shows the symptoms of disintegration and decay, diseases called dental fluorosis and skeletal fluorosis. Fluoride in drinking water at low $(<0.5 \mathrm{mg} / \mathrm{l})$ and high concentration $(>1 / 5 \mathrm{mg} / \mathrm{l})$ can cause dental caries and dental fluorosis diseases, respectively. The permissible limit of 
fluoride in drinking water is $1.5 \mathrm{mg} / \mathrm{l}$ as per BIS standard. The fluoride concentration in groundwater of the area varies from 0.19 to $2.4 \mathrm{mg} / \mathrm{l}$ with an average value of $0.855 \mathrm{mg} / \mathrm{l}$ as shown in fig-4.

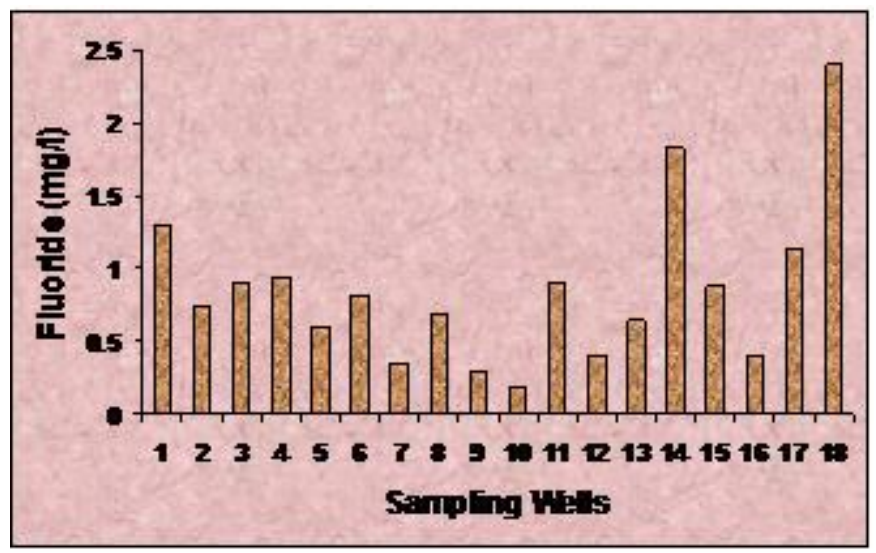

Fig-4: Variation of Fluoride

\subsection{Copper $\left(\mathrm{Cu}^{-}\right)$}

The quantity of copper compounds in nature is little or rare. $\mathrm{Cu}^{-}$enters the groundwater from weathering of minerals and rocks which contain copper. Copper $\left(\mathrm{Cu}^{-}\right)$is essential to human life and health but, like all heavy metals, is potentially toxic as well as continued inhalation of $\mathrm{Cu}^{-}$containing spray is linked with an increase in lung cancer among exposed worker. The copper concentration in the study area was found 0.05 to $0.2 \mathrm{mg} / \mathrm{l}$ with an average of $0.07 \mathrm{mg} / \mathrm{l}$ (Fig-5). The BIS has recommended $0.05 \mathrm{mg} / \mathrm{l}$ as the desirable limits and $1.5 \mathrm{mg} / \mathrm{l}$ as the permissible limit in the absence of alternate source. $\mathrm{Cu}^{-}$is an essential element, concentrated in several enzymes and its presence in trace concentration is essential for the formation of hemoglobin. An over dose of copper may lead to neurological complication, hypertension, liver and kidney dysfunctions [15]. Ingestion of copper causes, infant death, and short lived vomiting, diarrhea etc [16]. In the study area all the samples are within the permissible limit as suggested by [17]. Beyond $0.05 \mathrm{mg} / \mathrm{l}$ the water imparts astringent taste and cause decoloration and corrosion of pipes, fittings and utensils. In general the principal sources of copper in water supplies are corrosion of brass and copper pipes and addition of copper salts during water treatment for algae control. The toxicity of $\mathrm{Cu}^{-}$to aquatic life is dependent on the alkalinity of the water. At low alkalinity, $\mathrm{Cu}^{-}$is generally more toxic to aquatic life. The industrial sources of $\mathrm{Cu}^{-}$that enhances the concentration in groundwater include industrial effluents from electroplating. The concentration of $\mathrm{Cu}^{-}$in all groundwater samples exceeds the desirable limit but within the permissible limits of drinking water. Trace amounts of copper are required for the photosynthesis of haemoglobin and several human enzymes [18], whereas if high concentration of $\mathrm{Cu}^{-}$is consumed it may lead to neurological complications, hypertension, liver and kidney problems.

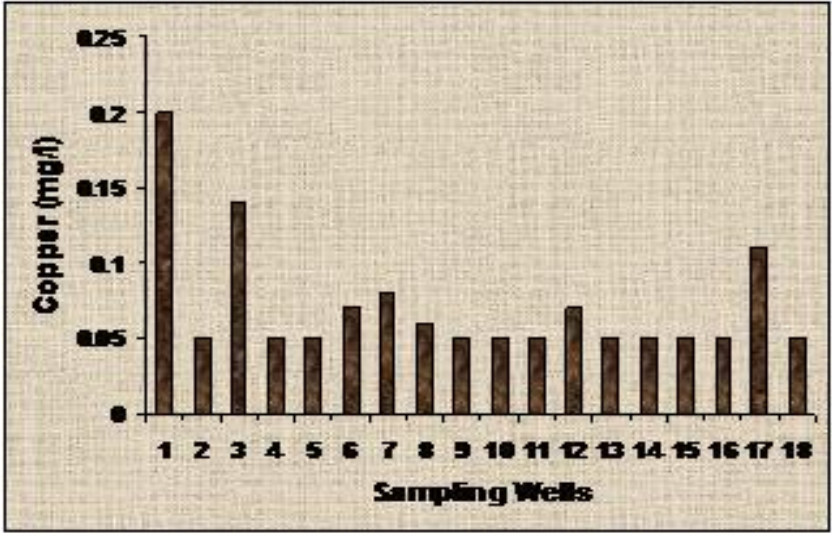

Fig-5: Variation of Copper

\subsection{Chromium (Cr)}

In the present study the concentration of chromium ranges from 0.02 to $0.21 \mathrm{mg} / \mathrm{l}$ with an average of $0.07 \mathrm{mg} / \mathrm{l}$ (Fig.6). Tannery effluent is mostly characterized by high salinity, high organic loading and specific pollutants such as chromium. Chromium $\left(\mathrm{Cr}^{-}\right)$is used to convert the skin into leather, being used in excess for improve the quality of the tanning process [22]. However, only $60-80 \%$ of $\mathrm{Cr}^{-}$is absorbed by the leather and the remaining is usually discharged in the sewage system [22]. These metals are toxic and even in small concentrations cause diseases in humans and animals. The $\mathrm{Cr}^{-}$is highly toxic to humans even in low concentrations. The major source of $\mathrm{Cr}^{-}$ is the effluent from tanneries as they use chrome sulphate which is an essential chemical in the tanning process. A concentration of $0.05 \mathrm{mg} / \mathrm{l}$ has been recommended as a desirable limit for drinking water [17].The standard gives no relaxation for $\mathrm{Cr}^{-}$concentration in drinking water. Studies of groundwater in this area have high concentrations of $\mathrm{Cr}^{-}$, which is much more than the permissible limit in drinking water. The tanneries are polluting the groundwater causing ecological degradation and health hazards. High concentration of chromium may be due to various anthropogenic activities like industrial effluent from tanneries and household sewages [23].

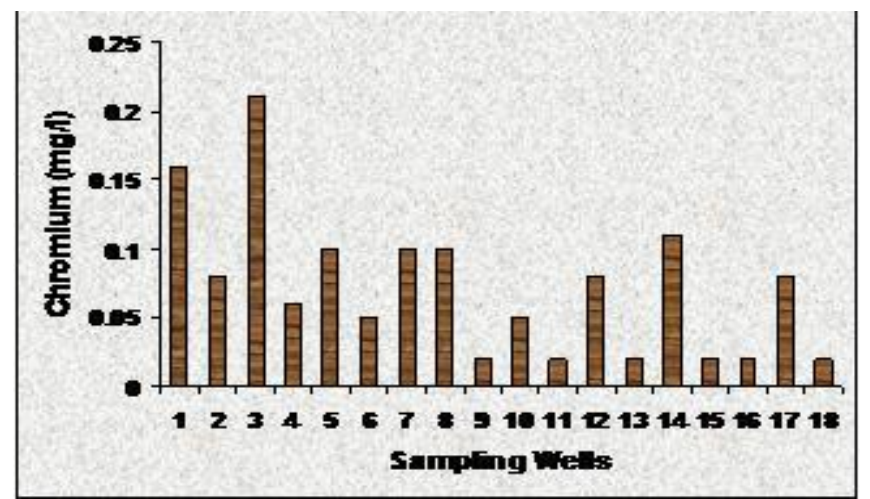

Fig-6: Variation of Chromium 


\subsection{Lead (Pb)}

Lead is an undesirable trace metal less abundantly found in earth crust. Lead is long been recognized as a harmful environment pollutant [24]. It is also one of the environmental threat that affect health of children. Automobile exhaust fumes have been reported to account for about $50 \%$ of the total inorganic $\mathrm{Pb}$ absorbed by human

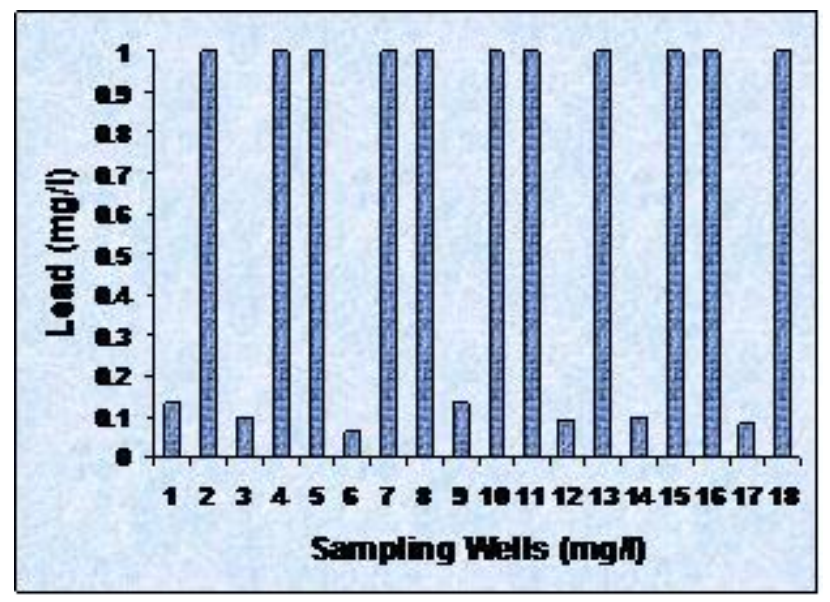

Fig-7: Variation of Lead

beings [25]. Lead is used principally in production of leadbatteries, from sewage effluent runoff of wastes, atmospheric deposition, solders and alloys. Lead is also found in soil, vegetation, animal and food. It is serious cumulative body poisons. Lead inhibits several key enzymes involved in the overall process of haemosynthesis, whereby metabolic intermediate accumulates. Lead is available in many minerals such as galena, cerussite and anglesite [26]. Lead is toxic to the central and peripheral nervous system causing neurological and behavior effects. The consumption of lead in higher quantity may cause behavioral problems, hearing loss, high kidney damage, reduced IQ, decreased sperm production, blood pressure and hypertension and eventually it may be prove to be fatal. Fertilizers, industrial activities (batteries and paints) and human activities are the source of $\mathrm{Pb}$ [10]. Lead in the environment may derive from either natural or anthropogenic sources. The lead concentration in the area ranges from 0.06 to $1.00 \mathrm{mg} / \mathrm{l}$ with an average of $0.65 \mathrm{mg} / \mathrm{l}$ (Fig.7). The concentration of lead in most of samples exceeds the safe limit of $0.05 \mathrm{mg} / \mathrm{l}$ beyond this limit the water becomes toxic. This may be attributed to industrial and human activities.

\subsection{Zinc (Zn)}

Concentration of free zinc ion in the earth's crust is low because the minerals which contain zinc ion have low solubility within the $\mathrm{pH}$ range of most natural water [27].The source of zinc in water is from weathering of the minerals and rocks which contain zinc. Fertilizers, animals and organic remains and the industrial activities are considered another source of zinc [10]. Zinc is essential element in plant and animal but excessive amounts will be harmful to human being [28]. Zn has been found to have low toxicity to man and only prolonged consumption of large doses can result in fatigue, dizziness and neutropenia [29]. Zinc could be toxic to some aquatic organisms such as fish [30]. Zinc concentration of groundwater samples ranges from 0.02 to $0.36 \mathrm{mg} / \mathrm{l}$ with an average of $0.071 \mathrm{mg} / \mathrm{l}$ (Fig.8). Zinc concentration in the area is less than the permissible limit and this means there is no zinc pollution in the groundwater of the area.

\subsection{Hydrochemical Facies}

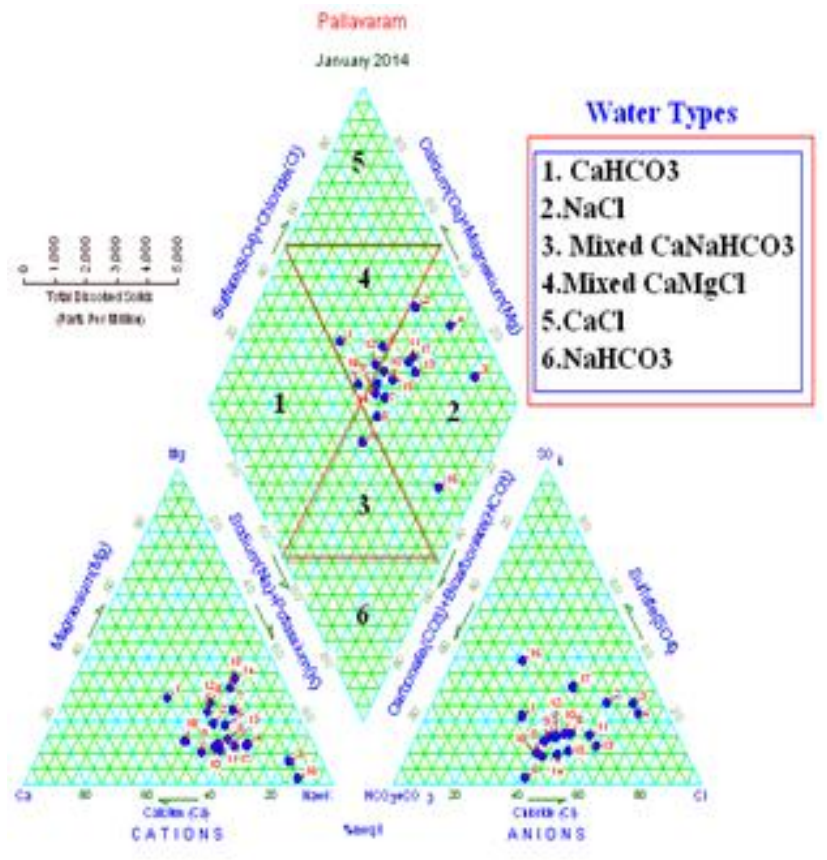

Fig-8: Piper Plot

To understand geochemical evolution, groundwater type, mixing of water from different sources and physiochemical process of groundwater in the area, [31] Piper diagram has been used. In the diagram, a point on the left triangular part for a particular location or sample, represents the major cations like $\mathrm{Ca}^{2+}, \mathrm{Mg}^{2+}, \mathrm{Na}^{+}$plus $\mathrm{K}^{+}$and a point on the right one represents the major anions like $\mathrm{Cl}^{-}, \mathrm{HCO}_{3}{ }^{-}, \mathrm{SO}_{4}{ }^{2-}, \mathrm{CO}_{3}{ }^{-}$. Both these points together in the diamond shaped part as a single point. The points explain the overall chemical character of the groundwater of that particular location. The groundwater type of the study area was distinguished and grouped by their position on a piper diagram (Fig-8). Based on the major cations and anion, the groundwater composition of the area was dominated by $\mathrm{Na}^{+}$and $\mathrm{Cl}^{-}$. Its source is believed to be mainly to industrial effluent, as $\mathrm{Na}^{+}$and $\mathrm{Cl}^{-}$are the main ions form this facies. 


\subsection{Health Impacts}

The population of the study area is 2, 16,308 based on 2011 census. To analyze the general conditions of the study area, field survey was conducted during the second week of March 2014. Questionnaire was prepared containing twenty seven questions. Field survey was conducted and aimed to get data from minimum 50 families.

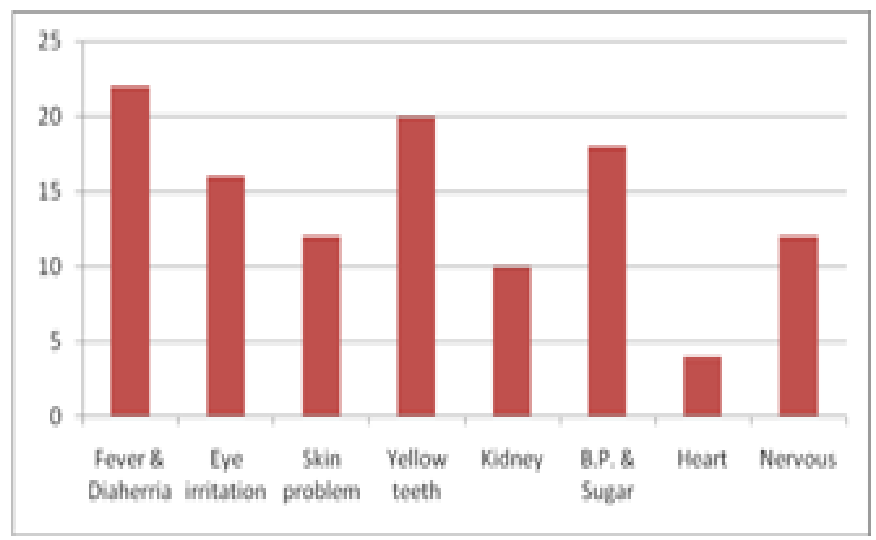

Fig-9: Graph showing the pronounced disease

Since the water is heavily contaminated with respect to many Physico-chemical parameters in industrially polluted and solid waste contaminated site, the water is not used for drinking purpose among all classes of people. But the people in polluted area use the groundwater sometimes for domestic purpose other than drinking. When the water is used by people for bathing and washing, the soap does not produce froath and also it causes skin rashes, itching, fever, diarra and this impacts is particularly experienced among the children within the age group of $<5$ years of age. It is not only that the groundwater is affected by leaching in the study area but also the waste from the industries dumped at the Periya Eri is causing groundwater related problems. Thus the polluted groundwater alone is not posing threat to human health but also the dumpsite serve as a habitat for many pathogenic organisms. Thus, the health of the people in Pallavaram near the Industrial area is under serious threat.

\section{CONCLUSIONS}

The concentrations of heavy metal $\mathrm{Cr}$ is threatening and thereby posing a serious health hazard. It is not that the effect is alone to human health but also economical in way that the people has to spend a reasonable part of their income towards purchasing better quality water for drinking and other domestic needs as a precautionary measure to avoid health impacts. Thus indirectly in a way to avoid health impacts the social cost of living of the people is made high. Thus, there is as alarming need to mitigate the water quality problems due to heavy metals in the study area.

\section{ACKNOWLEDGEMENTS}

The authors are thankful to the Students Mr.R.Balaraman, Mrs.E.Celinemary, Mrs.R.Kalpana and Mrs.E.Ramanichandra, B.E. (Civil Engineering), Part-Time, Anna University, Chennai, for their assistance in the groundwater quality analysis.

\section{REFERENCES}

[1]. Ramakrishnaiah K.M., Sadashivaiah.C. and Ranganna.G. (2009). Assessment of water quality index for the groundwater in Tumkur Taluk, Karnataka State, India, E-Journal of Chemistry, 6(2), 23-530.

[2]. Massod Alam., Sumbul Rais. and Mohd Aslam. (2009). Hydrochemical survey of Groundwater of Delhi, India, EJournal of Chemistry, 6(2), 429-436

[3]. WHO. (1995). Guidelines for Drinking Water Quality, World Health Organization, Geneva, Switzerland, 121

[4]. Aycicek, M., Kaplan.O. and Yaman M. (2008). Effects of Cadium on germination, seeding growth and metal contents of sunflower, Asian Journal of Chemistry, 2663-2672

[5]. Aschner M.(2002). Neurotoxic mechanism of fish-bone methylmetry, Environmental Toxicology and Pharmacology, $12,101-102$

[6]. Elizabeth K.M. and Premnath Naik. L. (2005). Effect of pollutes water on human health, Pollution Research, 24(2), 337-340.

[7]. APHA. (1995). Standard methods for the examination of water and wastewater, $21^{\text {st }}$ Edn, Washington D.C

[8]. Berkowitiz B., Dror.I. and Yaron.B. (2008). Contaminant Geochemistry, Springer-Verlag Berlin Heidelberg, 412

[9]. Boyd C.E. (2000). Water quality an introduction, Kluwer Acadeic publisher, USA, 330

[10]. Hem. J.D. (1985). Study and interpretation of the chemical characteristics of natual waters, 3rd edn, USGS water supply paper 2254 , 17-120.

[11]. Todd. D.K. (1980). Groundwater Hydrology, Wiley New York, 336.

[12]. Ragunath. (1987). Groundwater, $2^{\text {nd }}$ edition, Wiley Eastern Limited, 563

[13]. Sawyer. C. and McCarthy P.(1967). Chemical and sanitary engineering, $2^{\text {nd }}$ edn, McGraw-Hill, New York

[14]. CPCB.(2008). Guidelines for water quality management, Central Pollution Control Board, Parivesh Bhawan, East Arjun Nagar, Delhi

[15]. Khan S., Cao Q., Zheng, Y.M., Huang Y.Z. and Zhu Y.G. (2008). Health risks of heavy metals in contaminated soils and food crops irrigated with wastewater in Beijing, China, Environmental Pollution, 152, 686-692.

[16]. Barzilay J.I. (1999). The water we drink: Water quality and its effect on health, New Brunswick New Jursey, Rutgers University Press, 152.

[17]. Bureau of Indian Standards (BIS) (1991). Indian standard specification for drinking water, ISI 10500, New Delhi 
[18]. Cohen S., Creeger S.M., Carsel R.F. and Enfield C.G. (1984). Potential of pesticides contamination of groundwater resulting from agricultural uses American Society, 297

[19]. Rao M.S., Gopalkrishnan R. and Venkatesh B.R.(2001). Medical geology-An emerging field in environmental science, National Symposium on Role of Earth Sciences GSI Spl. Pub No 65, 213-222.

[20]. Krishna A.K. and Govil P.K. (2004). Heavy metal contamination of soil around Pali industrial area, Rajasthan, India, Environmental Geology, 38-44

[21]. Brindha K., Elango.L. and Rajesh V.G. (2010). Occurrence of Chromium and Copper in groundwater around tanneries in Chrompet area of Tamil Nadu, Indian Journal of Environmental Protection, 30(10), 818-822.

[22]. Arfaoui S., Srasra E. and Frini-Srasra N.(2005). Application of clays to treatment of tannery sewages, Desalination, 185, 419-426

[23]. Yadav Janeshwar,, Pathak R.K. and Khan Eliyas. (2013). Analysis of Water Quality using Physico-Chemical Parameters Satak Reservior in Khargone District MP, India, International Research Journal of Environmental Science ,2(1), 9-11.

[24]. Goering P.L., Waalkes M.P. and Klaassen C.D. (1994). Toxicology of metals, In:Goyer R.A and Cherian M.G (eds) Handbook of Experimental Pharmacology, Springer, New York, 115,189.

[25]. Mohan B.S. and Hosetti B.B. (1998). Lead toxicity to Salvinia natans grown in macrophyte ponds, Environmental Monitoring, 81, pp.3-7.

[26]. Emsley J. (1998). The elements ( $3^{\text {rd }}$ ed), Clavendon press, Oxford, London, 292.

[27]. Boyd A.S., Seger D., Vannucci S., Langley M., Abraham J.L. and King L.E.(2000). Mercury exposure and cutaneous disease. Journal of the American Academy of Dermatology, $43,81-90$.

[28]. WHO. (2007). Guide line for drinking water quality, Recommendation, $4^{\text {th }}$ edn, World Health Organization.

[29]. Hess R. and Schmid B. (2002). Zinc supplement overdose can have toxic effects, Jornal of Pediatric Hematology/Oncology Paediatr, 24, 582- 584.

[30]. Alabaster J.S. and Lloyd R. (1980). Water Quality Criteria for Fish $\left(2^{\text {nd }}\right.$ edn $)$. London Butteworths.

[31]. Piper A.M.(1984). A graphical procedure in the geochemical interpretation of water analysis, Am Geophys Union Trans, 25,914-923 